\title{
THE THEME OF PATRIOTISM IN PRINCE ROMAN
}

\author{
Joanna Kurowska
}

Independent scholar

\begin{abstract}
This essay explores Conrad's assessment of the moral state of Europe as well as postEnlightenment European divisions, as reflected in the writer's treatment of the theme of patriotism in his short story Prince Roman. The story's unique, seemingly "un-Conradian" features are discussed in the context of the influence of Polish Romanticist ideas on Conrad. The motifs of unselfishness and sacrifice for a "greater cause" recurring in Prince Roman are shown as determinants of the quality of the protagonist's moral choice.
\end{abstract}

Keywords: Prince Roman, patriotism, Poland, Europe, sacrifice, messianism, nationalism, Polish Romanticism

Published in 1910, the short story Prince Roman is Joseph Conrad's only piece of fiction that tackles the topic of his native Poland directly. The non-ironic treatment of its leading theme, patriotism, sets the story apart from the rest of Conrad's literary output. The aim of this essay is to analyze the theme of patriotism in Prince Roman in order to show that, at a deeper level, the idea of a person's love for his or her homeland, or the lack thereof, as depicted in the story, reflects Europe's political and cultural divisions, as Conrad saw them.

Conrad completed a draft of Prince Roman in September 1908, around the time when he worked on his memoir A Personal Record (cf. Najder, 1983[b], 346). Zdzisław Najder suggests that the novelist could have intended to include the story as a part of A Personal Record but on consideration separated the two pieces. Considering Conrad's avoidance of overt Polish themes resulting from his "unofficial dread of being found out" as to his Polish sentiments (cf. Choudhury, 40), the sudden appearance of Polish historical events and characters in two works published within a short period of time, is remarkable. Both pieces borrow material from the memoir of Conrad's uncle Tadeusz Bobrowski, published in 1901. Additionally, their creation could have been triggered by Robert Lynd's review of A Set of Six (1908), in which the critic attacked Conrad for not writing in Polish. Finally, working on A Personal Record, with which he wished to "make Polish life enter English literature" (Collected Letters 138), Conrad could have felt that his growing literary reputation created the proper "'psychological moment' for the success of such a book" (Knowles and Moore, 277). 
Indeed, with Prince Roman a slice of Polish life enters English belles-lettres. The plot of the story evolves around the November uprising of 1830-1831, the first of the two major nineteenth-century insurrections of the Poles against the Russian domination. ${ }^{1}$ The main protagonist is a prince named Roman (inspired by Prince Roman Sanguszko), who enlists as an ordinary soldier in the rebels' ranks. Several months before his decision to join the uprising, Roman lost his beloved wife. The involvement in the armed struggle for Poland's independence helps him to overcome despair and discover another emotional attachment, the love for his occupied country. Eventually, the Russians capture Roman, and then recognize him as the prince. Thanks to his family connections Roman receives the permission from the authorities to seek pardon, on the condition that he admits the insanity of his motives. He refuses and, as punishment, is condemned to twenty-five years of labor in Siberian mines.

Roman is a typical Conradian character in that he faces unexpected circumstances, in this case the death of his wife and the invasion of foreigners into his native land. Furthermore, he too "serves an idea," that of the struggle for national independence. However, a number of aspects make Roman an exceptional character in Conrad's fiction. Unlike Jim, whose idea of heroism blinds him against his own insufficiency and vulnerability, or Razumov, whose faith in the autocratic state prevents him from understanding its mechanisms of oppression; or the Goulds, who delude themselves as to the real role of the San Tomé mine in both Costaguana and their own lives; or Kurtz, whose idea of racial superiority makes him incapable of understanding the significance of his actions - unlike all those characters, Prince Roman does not experience destruction as a result of self-delusion. Conrad presents him as a genuine hero. The narrative repeatedly stresses the causality between Roman's romantic love and the pain of loss on the one hand, and the Prince's patriotic devotion on the other: "Her loss had been to him a moral shock. It had opened his heart to a greater sorrow, his mind to a vaster thought, his eyes to all the past, and to the existence of another love, fraught with pain, but as mysteriously imperative as that lost one to which he had entrusted his happiness" (164). Instead of using his typical corrosive irony to dissect Roman's choice, Conrad stresses genuine moral quality of the Prince's motives:

There is ferocity in every passion - even in love itself. The religion of undying hope resembles the mad cult of despair, of death, of annihilation. The difference lies in the moral motive springing from the secret needs and the unexpressed aspirations of the believers. It is only to vain men that all is vanity; and all is deception only to those who have never been sincere with themselves. (169, emphasis added)

The part of the narrative describing the Prince's state of mind during his imprisonment throws additional light on the perils of patriotic devotion in the Polish context:

Who can tell how much love of life there was in Prince Roman? How much remained of that sense of duty, revealed to him in sorrow? How much of his awakened love for his native coun-

${ }^{1}$ Albeit the story's inner narrator does not name the uprising directly, he mentions that the events "happened seventy years ago," which identifies the time of narration as 1900 or 1901. This has led some scholars (e.g. Adam Gillon and Ludwik Krzyżanowski) to suggesting 1901 as the time of conceiving or even drafting Prince Roman. 
try? - that country which demands to be loved as no other country has ever been loved, with the mournful affection one bears to the unforgotten dead and with the unextinguishable fire of hopeless passion which only a living, breathing, warm ideal can kindle in our breast. (172)

The phrases "that country which demands to be loved," "the mournful affection ... to the unforgotten dead" and "a living, breathing, and warm ideal" are derived from Polish Romanticism, hence they transport the significance of Roman's devotion from the level of personal motivation to the level of symbolic significance within Polish history. The Prince is no longer a detached "I" but the member of a community - the "we" from the beginning of the narrative: "in the presence of the world's passive indignation and eloquent sympathies we had once more to murmur "Voe victis!" and count the cost in sorrow" (29, emphasis added to the word "we"). Further, the image of the "unforgotten dead" as the object of love corresponds to the image occurring at the beginning of the story, where the inner narrator depicts the Poles as a "nationality not so much alive as surviving, which persists in thinking, breathing, speaking, hoping, and suffering in its grave railed in by a million of bayonets and triple-sealed with the seals of three great empires" (58). The "three great empires" being Russia, Prussia, and Austria - the countries which took over the territory of Poland in three consecutive partitions in 1772, 1793, and 1795- the "nation in the grave" echoes the quasi-religious interpretations of Poland's loss of national independence, developed during Romanticism and known as messianism. ${ }^{2}$ A number of Polish writers of that period adopted the idea — or some aspect of the idea - of the salvific significance of Poland's suffering and "death," parallel to Christ's suffering and death on the cross for the salvation of humanity. For example, in Ksiegi Narodu Polskiego i Pielgrzymstwa Polskiego (1832) —'Books of the Polish Nation and Polish Pilgrimage' ${ }^{3}$ - the leading Polish romanticist poet Adam Mickiewicz depicts the Polish nation as "martyred" by the three European rulers and "laid ... in the grave" (cf. 143); however, Mickiewicz asserts in his pamphlet, "the Polish nation did not die: its body lieth in the grave, but its spirit hath descended from the earth, that is from public life, to the abyss, that is to the private life of people who suffer slavery in their country" (ibid.).

Considering that Conrad's father, Apollo Korzeniowski was connected with Romanticism culturally, temperamentally, and in terms of his political involvement (he co-organized the other major Polish insurrection, the January Uprising of 1863),

${ }^{2}$ Messianic ideas first emerged in France, as a reaction to the trauma of the French Revolution. The Polish émigrés, including Adam Mickiewicz, could read in an 1830 issue of Le Globe: "La France a bu le calice révolutionnaire: elle l'a avalé d'un trait; la France a monté sur la croix. La France a été le Christ de nations" (qt. in Walicki 245). In its fully-fledged form messianism was "national and religious at the same time, [and] str[ove] for an imminent and total regeneration of earthly life" (243). In Poland, messianism emerged after the defeat of the November uprising. Again, it was a heterodox interpretation of Polish historical experience and of the moral state of Europe. The messianists blended their belief in a redemptive value of Poland's suffering with the "hope in an approaching total regeneration of humanity" (Walicki, qt. in Porter 28). Messianism both absorbed and nurtured the communal concerns of the Polish Romantics and allowed them - somewhat paradoxically - to express their programmatic universalism.

${ }^{3}$ Polish-language titles and excerpts appearing in this essay have been translated into English by the author. 
the appearance of the Romantic symbols, images, and motifs in Conrad's works is not surprising. As Najder observes, Conrad's youthful readings were "undoubtedly filtered through his daily intercourse with his father" (1997, 201-202). Conrad admitted this much in 1914, during his conversation with Marian Dąbrowski, when, referring to Mickiewicz's quintessentially Polish epic poem (1834), he said, "My father read Pan Tadeusz aloud to me, and made me read it out loud. Not once, not twice" (Dąbrowska, 44). Additionally, Conrad read Polish literature while attending schools in Kraków and Lwów. As Najder observes, in those schools "Polish Romantic poetry and patriotic literature were read and revered" $(1997,202)$.

In fact, not only the image of the "nation in the grave" but a number of Mickiewiczean motifs occur in Prince Roman. For example, the internal narrator observes that the Poles have never been "very good at calculating" (154), echoing Mickiewicz's announcement that amidst "all European powers" Poland "alone did not bow to the ... idol [of interest]" (Ksieggi... 140). In his fiction, Conrad frequently expressed his abomination towards "material interest." In Lord Jim, he playfully scrutinizes the seventeenth century Dutch and English adventurers' "passion for pepper," which burns "like a flame of love in [their] breast": "For a bag of pepper they would cut each other's throats without hesitation, and would forswear their souls, of which they were so careful otherwise" (165, emphasis added). Likewise, Mickiewicz laments that all European nations fought "over a factory, over a bale of cotton, and over a sack of pepper" (137, emphasis added). ${ }^{4}$

The presence of the Polish literary and cultural motifs in Prince Roman, the lack of the typical ironic exposition of some selfish aim as the protagonist's ultimate motive of action, the portraying of Roman as a genuine hero-all these aspects make Prince Roman an exceptional, in a way "un-Conradian" piece. The broader significance of this distinctiveness becomes clear in light of the frame narrator's discussion of patriotism. At the beginning of the story, the narrator puts that discussion in the context of modernity which appears "too refined" to appreciate patriotism: "I verily believe that we arrived at that subject through some exchange of ideas about patriotism - a somewhat discredited sentiment, because the delicacy of modern humanitarians regards it as a relic of barbarism" (154). The irony of this statement, targeting the "modern humanitarians," becomes obvious in juxtaposition with the following sentence: "It requires a certain greatness of soul to interpret patriotism worthily—or else a sincerity of feeling denied to the vulgar refinement of modern thought which cannot understand the august simplicity of a sentiment proceeding from the very nature of things and men" (ibid.). The word "sentiment" appearing in both quotations means patriotism.

The oxymoron "vulgar refinement of modern thought" contrasting with "august simplicity of patriotism" has a parallel in Conrad's novel Nostromo. Patriotism is the main topic of a lengthy conversation between Antonia Avellano and Martin Decoud. As a thoroughgoing skeptic, Decoud attempts to view Costaguana's politics from the position of a disengaged European: "All he saw and heard going on around him ex-

\footnotetext{
${ }^{4}$ More examples of Mickiewiczean motifs in Prince Roman can be found on page 7 of this essay. For a broader discussion of Polish literary motifs in Conrad's works, see Krzyżanowski and Morf.
} 
asperated the preconceived views of his European civilization. To contemplate revolutions from the distance of the Parisian Boulevards was quite another matter. Here on the spot it was not possible to dismiss their tragic comedy with the expression, 'Quelle farce!'" (176). Decoud's programmatic withdrawal stands in opposition to Antonia's philosophy of engagement and, paradoxically, her realism. She says to Decoud, "Yes, but you never see the aim. Men must be used as they are. I suppose nobody is really disinterested, unless, perhaps, you, Don Martin" (177). Antonia's "idealism" prompts her to engage in Costaguana's extremely complicated political and social life, while Decoud's skepticism has a paralyzing effect: "What is a conviction?" he asks, "A particular view of our personal advantage either practical or emotional. No one is a patriot for nothing. The word serves us well. ... I have no patriotic illusions" (189). Paradoxically, Decoud's romantic love for Antonia prompts him to act while his skepticism makes him question his very love: "I have only the supreme illusion of a lover" (ibid., emphasis added). Antonia and Decoud's expectations reflect their contrasting attitudes as well. He assures her that "his only aspiration [is] to a felicity so high that it seem[s] almost unrealizable on this earth," while the "idealistic" Antonia replies resolutely: "Why should any one of us think his aspirations unrealizable?" (193). She ends the discussion with a "declaration of involvement": "But we are labouring to change all that ... It is exactly what we desire. It is our object. It is the great cause. And the word [patriotism] you despise has stood also for sacrifice, for courage, for constancy, for suffering"s (187).

In light of this discussion, Prince Roman is an antithesis of Decoud, the "neither Jacob nor Job" who "neither wrestles nor protests" (Purdy 44). In contrast to Decoud's aloofness - and, for that matter, to the expansionism of Holroyd, Montero brothers, Gould, Kurtz, Almayer, etc. (all of whom serve "material interest") - the attitude of Prince Roman can be depicted as "yielding." Beside its rationale to protect the Prince's family from persecution by the Russian authorities, Roman's decision to enlist incognito in the insurrectionist army indicates that his motive is opposite to self-aggrandizement or expansion. There is no personal gain whatsoever in his decision and ensuing action; except, perhaps, gaining experience and acquiring greater capacity for compassion. Choudhury affirms that Roman's act signifies "genuine heroism" (55). The Prince returns home beaten up and scarred but as a more mature, more humane person. Having returned from Siberia to his native land, as a stone-deaf invalid, Roman devotes the rest of his life to the altruistic task of helping his compatriots.

The word "sentiment" recurs at the end of Prince Roman. On his return to Poland, the Prince asks someone to mediate (on behalf of one of his protégés) between him and his daughter and her husband, who both live in Vienna. Roman feels he cannot address his Viennese relatives personally, because "you see, my daughter and my

\footnotetext{
${ }^{5}$ The importance of this passage is magnified by the fact that Antonia has been modeled on Conrad's first love, Teofila Kałuska, who, like Antonia was an "uncompromising Puritan of patriotism with no trait of the slightest worldliness in her thoughts" ("Author's Note" to Nostromo xiv).

${ }^{6}$ Choudhury locates other examples of genuine heroism in the "sacrifice of Winnie's mother, in the endurance of Mrs. Haldin, [and] in the courage of ... Gaspar Ruiz" (55).
} 
son-in-law don't believe me to be a good judge of men. They think that I let myself be guided too much by sentiment" (175). The sentence closes the narrative. Considering the heroic portrayal of the Prince throughout the story, his involvement in the November uprising, his altruism after his return from Siberia - and considering Conrad's use of a number of Polish cultural and literary traits in the story-it seems obvious that the word "sentiment" ending the narrative symbolizes Prince Roman's patriotic commitment. Also, the final word "sentiment" corresponds to the same word at the beginning of the story, where it denotes patriotism. Once again the Prince's Polish "sentiment" becomes opposed to the "vulgar refinement" of the West, here represented by Roman's Viennese relatives. Since the Prince represents the Polish cause, the demarcation line in Conrad's story runs between Poland and Western Europe. Having adopted the "vulgar refinement of modern thought," the later is no longer capable of understanding the Polish "sentiment."

Conrad's sense of Poland's "otherness" within the European context-a sense he apparently shared with his compatriots - cannot be satisfactorily explained by stereotypes regarding Polish nineteenth century nationalism and its alleged influence on Conrad. ${ }^{7}$ Not only because, as Najder emphasizes, we should follow Johann Huizinga in making a "clear distinction between national awareness, the sense of nationality, and national consciousness on the one hand, and nationalism [as a tool of political manipulation] on the other" but also because there is "a clear distinction between 'nationalism' and 'patriotism"” (cf. "Joseph Conrad's Europe"). ${ }^{8}$ Pointing out that Conrad never used the term "nationalism, Najder adds that when he spoke about "the national spirit or temperament ... he had in mind national consciousness. And by the love of his country he meant patriotism in the sense as defined by Huizinga" (ibid.).

Conrad's awareness of Poland's "otherness" should be seen as a profoundly complex consciousness of a person who - to paraphrase Carola Kaplan- "saw himself as a subaltern within the shadow[s] of [multiple] dominant culture[s]" and who looked for ways to express his "Polishness" in his works addressed to the imperial English audience (cf. 135-136). Even if Conrad kept distance from Polish émigré circles, he had absorbed a great deal of the characteristics of - to use Alina Witkowska's termthe "ideal project of the Polish communal personality," as originated by - and maintained since - the so-called Great Polish Emigration (post-November), whose eminent representative was Adam Mickiewicz. According to Witkowska, among the aspects of the consciousness of that group was the sense of a link existing between patriotism and martyrdom, between Polish-ness and suffering. Witkowska also ob-

${ }^{7}$ For example, in The Strange Short Fiction of Joseph Conrad, while discussing the relationship between Conrad and Dostoevsky, Daphne Erdinast-Vulcan writes: "More recent discussions ... have recognized the complexity of that relationship: the interplay of Polish nationalism and Pan-Slavism, the mixture of strong psychological affinities and an equally intense personal antipathy" (15). In this excerpt, "Polish nationalism," allegedly inherited by Conrad, is taken as "given"; as something so obvious that it requires no further elaboration.

8 “Europa Józefa Conrada." See footnote 3.

${ }^{9}$ See footnote 3 . 
serves that as a community the Polish émigrés had preserved their sense of being "the missionaries of freedom; and only those who put their trust in the power of money could dismiss that attitude as one not to be taken seriously" (cf. Witkowska 84-85). Since Conrad knew that "with [Poles] religion and patriotism go hand in hand" (Carabine 98), his idea of patriotism entails the Christian idea of sacrifice. ${ }^{10}$ Thus, Roman's heroism is connected with sacrifice (unselfishness). Because there is no personal gain in his choice, his patriotic sentiment does not need an elaborate system of justifications, such as "civilizing the "savages" (Kurtz), "improving the economy" (Gould), "freeing the oppressed" (Victor Haldin), "converting the "heathen" (Holroyd), etc.

Ultimately, Conrad's avowal of the sentiment of patriotism in "Prince Roman" should be seen in the larger context of his ideal of fidelity, which, as Najder emphasizes, "was crucial to Polish nineteenth-century public morality." In the historical moment of the nineteenth-century foreign dominance, fidelity was "in the first place ... to the cause of national independence" $(1997,203)$. Fidelity, as well as ethics of honor, are rooted in Europe's medieval chivalric code, which stands in the "line of conservative ethics, of moral values and ideals, based on past experience, on tradition, not on abstract reasoning or visions of a better future" (ibid. 200). The opposition between Polish patriotism (represented by Prince Roman) and the "vulgar refinement of modern thought" of Western Europe reflects Conrad's recognition of European divisions as well as of the tension between Romanticism ("love") and the dogmatic rationalism of the Enlightenment ("idea"). Conrad's Romanticist leaning can be detected in his stressing the "simplicity" of the "sentiment of patriotism" that proceeds "from the very nature of things and men" (emphasis added). ${ }^{11}$ The idea of the "nature of things and men" suggests the existence of an external ontological order, which can be accessed through feelings. The polarity between the acknowledgment of such an order, to which man belongs, and the Cartesian view of the world as an object entirely within the grasp and command of the cognitive subject, reflects the fundamental rift within European consciousness, as Conrad had perceived it. For the novelist Poland - as Europe's very own "other"- becomes an epitome of the "Romantic" end of the polarity "Romanticism : Enlightenment." As Charles Taylor points out, "these two spiritual outlooks are in confrontation" (384) up to modern times, and "our cultural life, our self-conceptions, our moral outlooks still operate in the wake of these great events" (393). As a European, Conrad was the recipient of both "outlooks":

In Europe the old monarchical principle stands justified in its historical struggle with the growth of political liberty by the evolution of the idea of nationality as we see it concreted at the present time; by the inception of that wider solidarity grouping together around the standard of

${ }^{10}$ It is well known that Conrad detested Christianity as both institutional religion and scriptural rhetoric. However, as attested by John Lester and Dwight Purdy, his attitude towards religion was complex. For Conrad's treatment of the theme of Christian sacrifice see also Joanna Kurowska's essay "Moral and Religious Relativism in The Rover."

${ }^{11}$ Cf. Mickiewicz: "Tajemną mocą wytwarzającą ten cud narodowy był właśnie ów bóg nieznany, któremu na imię - patriotyzm Polaków" ("Precisely that unknown god, whose name is patriotism of the Poles, was the secret power creating the national miracle") (Dzieła, vol. IX 269). 
monarchical power these larger agglomerations of mankind. This service of unification, creating close-knit communities possessing the ability, the will, and the power to pursue a common ideal, has prepared the ground for the advent of a still larger understanding: for the solidarity of Europeanism, which must be the next step towards the advent of Concord and Justice; an advent that, however delayed by the fatal worship of force and the errors of national selfishness, has been, and remains, the only possible goal of our progress ("Autocracy and War" 96-97).

The ideas of "liberty" and "justice" evoked in this excerpt were well familiar to the thinkers of the Enlightenment. However, in opposing love (including patriotism) to material interest - or, on the moral plane, in opposing altruism to selfishnessConrad follows the Polish Romantics, who viewed their homeland's history as not only politically but also morally different from the histories of the countries that "bowed to the idol of material interest." For example, the poet Zygmunt Krasiński disapproves reductive materialism following the Industrial Revolution:

Wokół [Polski] Europa-bez czucia—bez dumy-
Zgrzyt kół stalowych-parociągów szumy-
I do bram giełdy cisnące się tłumy ... (274)
Around [Poland]_Europe-with no feeling—no pride-
The steel wheels'shriek — the steam trains'rattle
And the crowds pushing their way to the market.

It should be added, Conrad was aware that patriotism too can become a "fixed idea" and be used as a catchword in a political and military scramble for "material interest." As Charles Taylor points out, patriotism has been "woven into relations of dominance" (71), especially in the late nineteenth and twentieth centuries, the era of nationalism. ${ }^{12}$ Hence, Decoud's concerns expressed in Nostromo (as quoted earlier) are not without validity. In the fictional Costaguana, the Montero brothers use patriotism to enforce their own political agenda. Their press speaks "oracularly of the secret promises of support given by 'our great sister Republic of the North' against the sinister land-grabbing designs of European powers" (146). Seemingly, then, the brothers participate in the same kind of struggle in which Prince Roman is involved. However, the narrative of Nostromo stresses that General Montero's "moral motive springing from the secret needs and the unexpressed aspirations" is "everlastingly discontented vanity" (387). His brother Pedrito "had conceived the idea of an existence for himself where, like the Duc de Morny, he would associate the command of every pleasure with the conduct of political affairs and enjoy power supremely in every way" (ibid.). To carry out their ambitions, the brothers are "organizing an army, gathering malcontents, sending emissaries primed with patriotic lies to the people" (145, emphasis added). "Patriotic lies" in this excerpt spring from vanity, greed, and power-grab. Such selfish motivations remain in opposition to Prince Roman's selfless

\footnotetext{
${ }^{12}$ As opposed to Roman's patriotism, nationalism seems to mean the allegiance to an imagined historic group that considers itself ethnically, culturally, and linguistically pure. Nationalism projects the existence of a tradition and identity whose only change is its successive temporal progression. As such, it considers itself as "fixed." It tends to make the hate of another - to use Conrad's words pertaining to the anti-Polish attitudes among the Russians - "a cardinal article of patriotic creed" ("Prince Roman" 171) and thus it typically gets involved in protecting its "purity" by the means of political, cultural, and ethnic discrimination.
} 
patriotic devotion. Again, Conrad asserts, "the difference lies in the moral motive springing from the secret needs and the unexpressed aspirations of the believers" (169, emphasis added). Though both the Montero brothers and Prince Roman have "political agendas," it is selfishness or the lack thereof that determines the moral quality of a person's actions.

Keeping these reservations in mind, one can depict Roman's patriotism as the allegiance to a local tradition and culture, including its hybridities, its diverse ethnic, religious and linguistic groups and individuals, its historic and temporal alterations and its open-ended, unceasing search for self-definition and identity. Characteristically, in Prince Roman the members of diverse ethnic, religious, and social groups - the aristocrat Roman, the nobleman Francis, and the Jew Yankel - are patriots. As Conrad critics have frequently observed, Conrad modeled his Yankel on the Jewish innkeeper Jankiel, one of the key characters in Mickiewicz's Pan Tadeusz. ${ }^{13}$ Both protagonists share the patriotic sentiment: Jankiel is a "loyal Pole by reputation," Yankel is a "Polish patriot." Conrad follows Mickiewicz in presenting patriotism as an emotional attachment that is culturally, ethnically, and to an extent socially, inclusive. In the differentiation between patriotism - or love of a land and its traditions, and nationalism - a "love" for an imagined ethnically pure group adhering to an imagined "fixed tradition" within the clearly defined borders of a nation-state, there seems to be in play exactly this difference: "expanding" on the one hand, and "yielding" (making room for others) on the other. Conrad also reminds us in "Prince Roman" that, apart from "material interest," the "sentiment of patriotism" is a component of the Europe's common heritage. Even if the moderns consider it to be a "relic of barbarism," "neither [Michelangelo] who closed his eyes thinking of his city, nor St Francis blessing with his last breath the town of Assisi, were barbarians" (154). If patriotism means attachment to the local, then it stands directly in the way of totalitarianism, imperialism, corporate globalism, or any other "ism" aiming at erasing the distinctiveness (and potentially the rights) of a local "Other." In Carola Kaplan's words, "love-romantic, maternal, familial, communal" is an "aspect of human life that exceeds judgment" (275).

\section{ACKNOWLEDGMENT}

Parts of this paper were presented at the Joseph Conrad Society's Conference in London, United Kingdom; July 3-5, 2003.

\footnotetext{
${ }^{13}$ The significance of Jankiel is well depicted in Opalski and Bartal: "Jankiel the tavern keeper, a dignified traditional Jew with the appearance of a biblical patriarch, is a spiritus movens of [proNapoleonic] conspiracy. During Napoleon's Russian campaign of 1812, the Jew is instrumental in bringing a detachment of the glorious French army into the sleepy Lithuanian village. He acts as a secret emissary, adviser, and spy for his noble associates, who gather in his tavern to discuss politics and reinvigorate their patriotic feelings. As a trusted person at the center of communal life, Jankiel holds the key to all of the community's secrets and the real and assumed identities of all characters in the poem. He represents memory and continuity in his community, links them to universal historical events while acting as a dedicated preserver of Polish national tradition" (19-20).
} 


\section{WORKS CITED}

Carabine, K., “'Irreconcilable Antagonisms:' Reflections on Conrad, Poland, and the English Political Novel" [in:] Conrad and Poland, ed. A. Kurczaba, Lublin: Maria Curie-Skłodowska University Press, 1996, pp. 89-112.

Choudhury, S. I., The Moral Imagination of Joseph Conrad, Zindabahar: Asiatic Press, University of Dacca, 1975.

Conrad, J., Collected Edition of the Works of Joseph Conrad, London: J. M. Dent and Sons Ltd., 1946-1954.

---------, Collected Letters, vol. 4, ed. F. Karl et al. Cambridge: Cambridge UP, 1983.

Dąbrowska, M., Szkice o Conradzie, $2^{\text {nd }}$ ed., ed. E. Korzeniewska, Warszawa: Czytelnik, 1974.

Erdinast-Vulcan, D., The Strange Short Fiction of Joseph Conrad: Writing, Culture, and Subjectivity, Oxford: Oxford UP, 1999.

Gillon, A., "Some Polish Literary Motifs in the Works of Joseph Conrad," The Slavonic and East European Journal 1966, vol. 10(4), pp. 424-439.

Kaplan, C. M., "Beyond Gender: Deconstructions of Masculinity and Femininity from 'Karain' to Under Western Eyes" [in:] Conrad in the Twenty-First Century: Contemporary Approaches and Perspectives, ed. C. M. Kaplan et al., New York: Routledge, 2005, pp. 267-279.

Knowles, O., Moore G. M., Oxford Reader's Companion to Conrad, Oxford: Oxford UP, 2000.

Krasiński, Z., Pisma Zygmunta Krasińskiego, vol. VI, Wydanie Jubileuszowe [Jubilee Edition], Kraków: Gebethner i Spółka, 1912.

Krzyżanowski, L. (ed.), Joseph Conrad: Centennial Essays, New York: Polish Institute of Arts and Sciences in America, 1960.

Kurowska, J., "Moral and Religious Relativism in The Rover," The Conradian 2013, vol. 38(2), pp. 90-99.

Lester, J., Joseph Conrad's Religion, New York: St. Martin's Press, 1988.

Mickiewicz, A., Dzieła, vol. IX, Warszawa: Czytelnik, 1955.

--------, Dzieła poetyckie, ed. T. Pini, Warszawa: YPsylon, 1994.

Morf, G., The Polish Heritage of Joseph Conrad, London: S. Low, Marston \& Co., Ltd., 1930.

Najder, Z., Conrad in Perspective: Essays on Art and Fidelity, Cambridge: Cambridge UP, 1997.

-------- (ed.) [a], Conrad under Familial Eyes, transl. H. Carroll-Najder, Cambridge: Cambridge UP, 1983.

---------, “Europa Józefa Conrada,” Polski Przegląd Dyplomatyczny 2001, vol. 1(1), pp. 181-194.

------- [b], Joseph Conrad, a Chronicle, New Brunswick, NJ: Rutgers UP, 1983.

Opalski, M., Bartal, I., Poles and Jews: A Failed Brotherhood, Hanover: Brandeis UP, 1992.

Porter, B., When Nationalism Began to Hate: Imagining Modern Politics in Nineteenth-Century Poland, New York: Oxford UP, 2000.

Purdy, D., Joseph Conrad's Bible, Norman: University of Oklahoma Press, 1984.

Taylor, Ch., Sources of the Self: The Making of Modern Identity, Cambridge: Harvard UP, 2000.

Walicki, A., Philosophy and Romantic Nationalism: the Case of Poland, Notre Dame: University of Notre Dame Press, 1994.

Witkowska, A., Wielkie stulecie Polaków, Warszawa: Państwowy Instytut Wydawniczy, 1987. 